\title{
Faculty Transitions In Online Delivery: Make Or Buy? Tips For Developing A 'New To You' Online Course
}

\author{
Kelly Delaney-Klinger, University of Wisconsin-Whitewater, USA \\ Jeff Vanevenhoven, University of Wisconsin-Whitewater, USA \\ Richard Wagner, University of Wisconsin-Whitewater, USA \\ John Chenoweth, University of Wisconsin-Whitewater, USA
}

\begin{abstract}
In the last few decades, teaching courses online has become a standard practice at many colleges and universities. Although technologies and pedagogies have changed rapidly during this time, developing an online course is still a labor and time-intensive undertaking. With changes in staffing and course offerings, faculty are often faced with determining the most effective and efficient ways to assume responsibilities for online courses. The authors suggest that under particular ownership expectations there are three main approaches for faculty tasked with offering a course online: 1) develop a new course, 2) modify an already existing course, or 3) adopt an existing online course "as-is." Some decision guidelines and sample scenarios are offered to aid faculty in determining the best approach for launching or taking ownership of an online course offering.
\end{abstract}

Keywords: Online Course; Course Design; Course Ownership; Online Pedagogy

\section{INTRODUCTION}

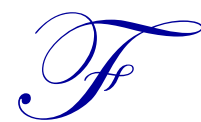

or many colleges and universities, teaching courses online is no longer a novel event. In fact, for some institutions, this method of teaching has been present for some time. Yet for others, the growth of online course offerings requires significant asset investment on behalf of the institution in new course development by instructors or course developers and is a very labor and time-intensive undertaking (Seaman, 2009; Wagner, Vanevenhoven, \& Bronson, 2010). In these initial stages of online course development, when instructors are asked and agreed to teach online, courses are often being offered online for the first time. As online programs have matured, technologies and pedagogies have changed creating additional challenges for conducting the offerings of these courses. Processes for developing new and/or revised courses now vary greatly among colleges and universities. In fact, as Porto \& Aje (2004) suggested, course development in any educational institution is strongly impacted by the "organizational structure and culture and consequent idiosyncrasies."

While there is a broad array of factors shaping decisions on creation or level of modification, that conversation well exceeds the purpose of this examination. We do, however, focus on the major choices instructors face as to whether they should make, modify, or simply inherit the components of an online course. Prior to the development of any course or course materials, particularly those used online, educational institutions and related staff must resolve the ownership issues associated with the materials. A variety of surveys and studies have suggested that faculty members seem to have very little understanding about ownership of course materials (Care \& Scanlan, 2001; Loddington, Gadd, Oppenheim, Bates, \& Manuel, 2006). In work-for-hire situations, it is expected that the university owns the course and materials because it has paid faculty to create them (DeGagne \& McGill, 2010; Kranch, 2008). In other circumstances, universities and faculty share ownership or split ownership on the basis of course materials (faculty) and the course (universities) (Bonk, 2001). As courses have incorporated more elaborate and expensive technologies, universities have become more interested in assuming ownership (Morgan, 2000). However, DeGagne and McGill (2010) and Petersen (2003) suggest that determining ownership and 
intellectual property rights of courses and materials will become even more difficult as new course content results from student interactions and contributions during a particular course session. Authorship, let alone ownership, will not be easy to ascertain. Obviously, these issues are made even more complicated by the variety of state and national laws under which faculty labor.

The variations across universities are impacted by several additional factors, including budget and resources devoted to the online programs. The least resource-intense approach for the university appears to be one in which the teaching faculty member serves as the course designer and developer, with only limited assistance and technical support from university services. In this lower-cost approach, faculty support is usually focused on training and the development of some standardized templates for course development. In this model, the ownership of the online course is often jointly shared by the university and the faculty member, such that either one can use the course at their discretion.

With greater resources, universities often move to a partnership approach for online course design and development. In this model, there are dedicated instructional designers and technical experts who work hand in hand with the faculty member (Xu \& Morris, 2007) to create the course structure and material and actually put the course online in the course management system. The faculty member creates or identifies the majority of materials but is assisted in making them electronically available. In this model, the ownership of the course is also often jointly shared by the university and the faculty member.

At the top of the resource scale is the model in which the course is designed and developed by a team of content, design and technical experts. This approach is becoming more and more common as online education becomes more sophisticated (Hixon, 2008). As Caplan and Graham suggested, "Quality courseware production requires a highly organized, concerted effort from many players" (p. 256). While these teams are created and implemented in a variety of ways (Care \& Scanlan, 2001), there are certain roles that are often utilized. For example, Hixon (2008) identified five that are generally expected: 1) project manager, 2) instructional designer, 3) subject matter expert, 4) technology support/production, and 5) other positions such as graphic artists. In this approach, the subject matter expert is likely one or more faculty members, but they may or may not be in line to teach the new course. Once the course is completed, it is then transferred among faculty members, both adjunct and tenure-track, as staffing needs require. As a result, any specific instructor of the course may or may not have been part of the design/development team. In this case, the course is owned exclusively by the university.

Based on the review above, we can see that the course development process can differ widely depending on the institution where the course is being developed. In some institutions, faculty may have little or no input on the course development process, while in other situations they are the principal developers of these courses and therefore must decide on an approach that meets their own needs as well as those of the students and the institution. The author's university has generally followed the first, lower-cost model where faculty developers have joint ownership of the course with the university. This results in faculty facing a series of decisions about balancing their own resources and capabilities with the desired design or structure of the course.

At universities, such as the author's which uses this lower-cost model, there are three main options from which faculty inheriting an existing online course can choose. The first is to start from scratch and develop the next version of the course as if this were the first time it was offered online. The second is to adopt the course "as-is," using both the structure and content as originally developed. This is akin to simply stepping into a course and continuing as if the instructor had never changed. Finally, the third main option is to adopt the structure and main content of the course, gradually replacing the instructor-specific materials over repeated teachings of the course. There are, of course, innumerable variations on these options, but for the purpose of discussion, this paper will focus on these three. It is important for faculty to consider the advantages and disadvantages of these approaches before determining which option to pursue.

\section{DEVELOPING A NEW COURSE}

As Xu and Morris (2007) and Twigg (2003) describe, there are a number of options for creating a brand new course. These include sole creation by the instructor, the use of a team-based approach involving several parties within the college or university, and the purchase and adoption of commercially produced course content and 
methodology. According to Massy and Zemsky (1995), many courses are developed and delivered idiosyncratically by individual professors, most likely because of the advantages faculty gain from creating a new course. For instance, creating or recreating a course from the very beginning allows the faculty member to ensure that his or her strengths and quirks are reflected in the course, just as they would be in traditional, face-to-face courses (Koehler, Mishra, Hershey, \& Peruski, 2004). It also allows the faculty member to use the format or structure with which they are most comfortable. In certain cases, starting over from the beginning may improve the quality and organization of the course (Care \& Scanlan, 2001) and in the long run make it easier if the adoptive instructor is required to offer the course repeatedly. With the advent of various online course and material-sharing sources (eg. MERLOT.org), faculty members now have the ability to obtain assistance and content from colleagues in other institutions.

Creating an all-new online course does come with some disadvantages. First, initial creation of a course can be extremely time-consuming, potentially involving hundreds of hours of work by the faculty member with or without additional time spent by instructional and technical experts. Miller and Rader (2010) suggest that this may be reasonable for tenure-track faculty as a job-related activity, but that it is unlikely that adjunct faculty would be properly compensated or supported for those developmental activities. However, even for tenure-track faculty, the issue becomes one of concern that the amount of time spent developing the course will prevent completion of other job requirements such as research and service (Bonk, 2001; Care \& Scanlon, 2001). In fact, Boice (2000) summarized decades of research on faculty success suggesting that "the most efficient and effective teachers delegate some of the responsibility, just as good managers do" (p. 76). In addition, even tenured faculty are rarely rewarded for the extra time spent developing an online versus traditional course (Luck, 2001). Finally, it should be noted that faculty without previous experience in online teaching may lack the knowledge and skills necessary to effectively apply the course management system used by the institution. Developing a new course would entail extensive training and/or trial and error experiences with the technology, adding additional time and costs to the process.

\section{REVISING AN EXISTING COURSE}

There are numerous variations between creating a course from scratch and simply using someone else's course with little adjustment. In general, a middle-ground approach may be to adopt the overall structure and materials associated with a particular online course. Initially, the new instructor would replace the material specific to the previous colleague, such as the personal stories, jokes, and videos/other recordings of the course developer. Over time, the course would be gradually adapted to the new owner's preferences, new material would be added, and the system would be tweaked to remain current and applicable to both the new instructor and current students. This approach requires less time than completely creating a new course, although admittedly more time than simply adopting someone else's course. It would also allow new faculty to assume responsibility for an online course without requiring an extensive investment of time or resources, a strategy that would seem especially valuable for a tenure track faculty member already juggling multiple requirements for promotion.

Faculty members who choose to gradually adapt someone else's online course to their own situation still face several potential challenges. First of all, there is very little guidance as to how to best utilize the existing structure of the course while customizing it for one's own preferences and styles. This same dilemma is encountered in traditional classes. Faculty, according to Boice (2000), know they can benefit from others' experiences, yet there is often no clear guideline as to how much of someone else's materials is appropriate to include in a course, as well as how to best recognize the contributions of that instructor. In addition, it is possible that the originating instructor may try to retain some level of ownership, either in terms of intellectual property or by more symbolic means, in "his/her" class, especially if that person is not leaving the institution. A new instructor may be monitored and critiqued for attempting to alter the course too extensively.

\section{ADOPTING AN EXISTING COURSE “AS-IS”}

When inheriting an online course, a faculty member can also choose to simply implement the course "asis," completely using the content and structure created by the course originator. This assumes that the course and accompanying materials are freely given with the intention that the adopting instructor will use the materials as he or she sees fit and that this use does not violate any ownership expectations. Much of the discussion in pedagogical 
circles about this option has focused on the issue of plagiarism or other violation of intellectual property rights (Gasaway, 2002). One exception is the aforementioned work by Boice (2000) in which he differentiates "quick starter" faculty from those less successful: "They [quick starters] also cheerfully admit that most teaching is the borrowing and restating of old ideas. ... [and they] enjoy sharing the credit for collaboration..." (p. 76).

Based on personal experience, Deubel (2003) suggests that there are four advantages from adopting another faculty member's course. In this case, the recipient benefits from the time saved by having others responsible for the design elements of the course and for selecting and/or modifying a particular course system. In addition, because the course is fully prepared, the instructor is able to focus on implementation and e-moderating, which are at the core of successful online experiences for students. Finally, starting with another's course gives an instructor time to discern which course elements are most desirable for creating additional online courses. This would be especially appropriate when an instructor has little prior online teaching experience or will only be facilitating the course once in the near future.

Despite the advantages of stepping into an existing course, instructors must be careful when adopting this course of action. For instance, instructors tend to include course material that closely reflects their own values, preferences, and interests. This may include particular jokes, activities, and course objectives that do not easily transfer to a different instructor. Sharing someone else's "war stories" or jokes can be just as awkward in the online environment as it is in a traditional course. The validity of the material will occasionally appear suspect, leading students to blame the new instructor for aspects of the course he/she did not develop (Deubel, 2003). As suggested above, it is typically assumed that instructors willingly and gladly share course materials with one another. In situations where the intellectual property, by definition, belongs to the university, this may be a reasonable expectation. However, when course materials belong to the instructor, some faculty may feel more possessive of their materials and be far more reticent to share with a colleague. In this case, it may be more difficult for the new instructor to assume the level of ownership necessary to be engaged fully in the educational process (Deubel, 2003).

How does an instructor decide how much customization is necessary when moving into an existing online course? There are a number of factors that are helpful to consider when determining whether to create a new course, adopt the existing course as-is, or gradually modify an existing course until it best reflects the instructor's own needs and preferences. Tenure-track and adjunct faculty regularly face numerous challenges in administering welldesigned, efficient, and effective courses while also meeting the research and/or service requirements of their positions. One of these challenges certainly occurs when the responsibility for an online course is shifted from one faculty member to another. Therefore, to ensure professional success, as well as the quality of the course, it is critical that the inheriting instructor find the most appropriate methods for assuming responsibility of a new online course. The factors useful in making this determination are described below and summarized in Table 1.

\section{Decision Characteristics to Consider}

While there are no generally accepted rules for how to proceed, there are some characteristics that can serve as 'guidelines' on which of the choices (new, as-is, or revise) is best in a given situation.

First, and most obvious, is how much time the instructor has to develop the course. Developing a course from scratch is the most time-intensive option and often requires six months or more lead time. For most faculty members, these efforts come in combination with many other activities, such as face-to-face teaching, research, writing, and meeting service obligations. How much time is available to allocate to the development of the course?

The second factor to consider is how many times the instructor can expect to teach the course online in the future. Will this be a long-term teaching load commitment for this instructor or will others be hired/assigned to teach the course?

Next, it is important to identify the instructor's familiarity with the course. Is this a course previously taught in the classroom, for which the instructor has accumulated a great deal of insight and material, or is this course entirely new? If it is totally new, the instructor's first effort might be little more than a pilot test of the course - meaning a lot of changes will be made from the first to the second time the course is taught. Maybe just using an existing course the first time and then identifying the changes needed might make the most sense. 
How much structure does the course have built into it? Some courses use a good textbook and have a clear direction and flow for teaching. These also often use a lot of exams and graded objective assignments. Other courses do not have that kind of a foundation and are based on group discussions and subjective assignments. Developing the second kind of course can be more time-consuming - a factor to look at when making development decisions.

Is this the instructor's first online course or is the instructor a veteran at on-line education? For example, one of the authors of this paper is developing a first online course and one currently teaches six different online courses.

In addition, it is important to consider the related issue of familiarity with the course management software (CMS). The length and depth of experience with the CMS can make a big difference in how an instructor should proceed.

Table 1 presents a summary of these six points and some additional guidelines that should be useful for making decisions about a new (to you) online course.

Table 1: Decision Matrix

\begin{tabular}{|c|c|c|c|}
\hline & $\begin{array}{c}\text { Characteristics } \\
\text { Suggesting Developing A } \\
\text { New Course }\end{array}$ & $\begin{array}{c}\text { Characteristics Suggesting } \\
\text { Revision of The Existing } \\
\text { Course }\end{array}$ & $\begin{array}{l}\text { Characteristics Suggesting } \\
\text { Adopting Course "As-Is" }\end{array}$ \\
\hline $\begin{array}{l}\text { How much time does } \\
\text { instructor have to invest in } \\
\text { course creation? }\end{array}$ & $\begin{array}{l}\text { Extensive time (ex. } \\
\text { Reduction in teaching } \\
\text { load; long lead time before } \\
\text { offering course) }\end{array}$ & $\begin{array}{l}\text { Moderate lead time } \\
\text { Assigned } \\
\text { semester or summer prior; } \\
\text { tenure-track faculty with } \\
\text { heavy teaching load) }\end{array}$ & $\begin{array}{l}\text { Minimal time (ex. Sudden } \\
\text { replacement of prior } \\
\text { instructor; instructor in first } \\
\text { semester of employment) }\end{array}$ \\
\hline $\begin{array}{l}\text { How many times will } \\
\text { instructor be facilitating the } \\
\text { course? }\end{array}$ & $\begin{array}{l}\text { Numerous (ex. Faculty } \\
\text { member assigned to teach } \\
\text { course into the foreseeable } \\
\text { future) }\end{array}$ & $\begin{array}{l}\text { Multiple but not on a } \\
\text { permanent assignment (ex. } \\
\text { Faculty rotate teaching } \\
\text { assignments over time) }\end{array}$ & $\begin{array}{l}\text { Once (ex. Faculty member is } \\
\text { covering another's sabbatical } \\
\text { or medical leave) }\end{array}$ \\
\hline $\begin{array}{l}\text { How many times has } \\
\text { instructor taught the course } \\
\text { in a traditional, in-class } \\
\text { format? }\end{array}$ & $\begin{array}{l}\text { Numerous (ex. Faculty } \\
\text { member has well-designed } \\
\text { course to transfer to an on- } \\
\text { line format) }\end{array}$ & 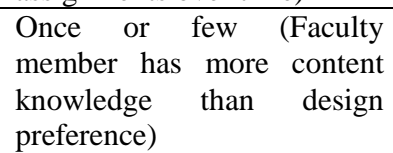 & $\begin{array}{l}\text { None (ex. On-line } \\
\text { assignment is first time } \\
\text { instructor offers course) }\end{array}$ \\
\hline $\begin{array}{l}\text { What is the desired level of } \\
\text { structure for the course? }\end{array}$ & $\begin{array}{l}\text { Low (ex. Discussion- } \\
\text { based, current topics, or } \\
\text { student-led course) }\end{array}$ & $\begin{array}{l}\text { Moderate (ex. Combination } \\
\text { of open-ended discussions or } \\
\text { coverage of material and } \\
\text { traditional topic format) }\end{array}$ & $\begin{array}{l}\text { High (ex. Basic introduction } \\
\text { course that covers same } \\
\text { topics, follows step-by-step } \\
\text { progression of topics) }\end{array}$ \\
\hline $\begin{array}{l}\text { How much experience does } \\
\text { the instructor have in online } \\
\text { course development? }\end{array}$ & $\begin{array}{lcr}\begin{array}{l}\text { Significant } \\
\text { numerous }\end{array} \begin{array}{c}\text { (ex. } \\
\text { revisions }\end{array} & \text { of } \\
\text { other courses, } & \text { or } \\
\text { developed } & \text { other } & \text { new } \\
\text { courses) } & & \\
\end{array}$ & $\begin{array}{l}\text { Moderate (ex. Has developed } \\
\text { portions of a course or done } \\
\text { gradual revision of another } \\
\text { course) }\end{array}$ & Nor \\
\hline $\begin{array}{l}\text { How much experience does } \\
\text { the instructor have in the } \\
\text { course management system? }\end{array}$ & $\begin{array}{l}\text { Significant (ex. Has taught } \\
\text { numerous classes in the } \\
\text { CMS utilizing most of the } \\
\text { CMS features) }\end{array}$ & $\begin{array}{l}\text { Moderate (ex. Has taught } \\
\text { few courses in the CMS or } \\
\text { not used many of the CMS } \\
\text { features) }\end{array}$ & $\begin{array}{l}\text { None (ex. Has never taught } \\
\text { online before or has taught } \\
\text { online but not with the } \\
\text { current CMS) }\end{array}$ \\
\hline
\end{tabular}

Table 1 provides some guidance for faculty asked to teach an online course. In addition, the following scenarios further demonstrate the use of Table 1 in making decisions regarding the creation of online courses.

Scenario A

A new undergraduate course is being offered for the first time next fall (six months away). The tenured instructor scheduled to teach the course online has taught the class in a traditional classroom setting for over ten years and regularly teaches five other courses online (at various times). Applying Table 1 suggests the following: 
- $\quad$ Planning time is plentiful (New Course)

- $\quad$ Course will be taught online each fall for the foreseeable future (New Course)

- Instructor is very familiar with the course (New Course)

- $\quad$ Structure of course - this is a junior/senior level major course - moderate in format (Revision)

- Instructor has a high level of experience in developing online courses (New Course)

- $\quad$ Familiarity with CMS is high (New Course)

The characteristics of this scenario suggest that developing this as a new course is the best option.

\section{Scenario B}

A new tenure track instructor scheduled to teach the course online has taught the class in a traditional classroom setting and currently teaches three other courses. Applying Table 1 suggests the following:

- $\quad$ Planning time is moderate (Revision)

- $\quad$ Course will be taught online each spring for the foreseeable future (New Course)

- $\quad$ Instructor is moderately familiar with the course (Revision)

- $\quad$ Structure of course - this is a senior level major course - not highly structured in format (New Course)

- Instructor has little experience in developing online courses ("As-Is")

- $\quad$ Familiarity with CMS is moderate (Revision)

The characteristics of this scenario indicate to the instructor that revising an existing course is the best option.

\section{Scenario $C$}

An established undergraduate course is being offered online next fall (two months away). The tenured instructor scheduled to teach the course online cannot teach the course (unexpected retirement, health issue, etc.). The tenured faculty who asked to teach this course as an overload has only taught this class twice previously, and only in the traditional classroom. Applying Table 1 suggests:

- Planning time is minimal (Adopt "As-Is")

- $\quad$ Course will be taught online one time before a permanent replacement faculty member is hired (Adopt "AsIs")

- Instructor is familiar with the course (Gradual Revision)

- $\quad$ Structure of course - this is a senior level major course - not highly structured in format (New Course)

- Instructor has a low level of experience in developing online courses (Gradual Revision)

- Familiarity with CMS is low (Adopt "As-Is") best option.

The characteristics of this scenario indicate to the instructor that adopting this new course "As-Is" is the

\section{CONCLUSION}

Developing online courses demands significant effort and involves many factors that play into the decision process of how to best create and administer online courses. It is important to remember that Table 1 and the resulting decision options are only recommendations; there may be overriding concerns that dictate choice as there are many factors, including those not presented in this paper. Previous literature has categorically recommended development of course content by the person providing the instruction. In contrast to this opinion, the authors offer other options based on the practicality of other more pressing demands. If all indicators, except the lead-time, points to a new course, Table 1 would indicate that developing a new course is indeed the best option, regardless of how much time is actually available for development. If the lead time were only a few days due to an unexpected event, such as a serious illness that befell the original instructor, it would not be feasible to develop a completely new 
course. This particular suggestion appears to differ from the previous literature by recognizing that there may be other practical considerations which need to be factored into the decision process.

\section{AUTHOR INFORMATION}

Kelly Delaney-Klinger earned her Ph.D. in organizational behavior/human resource management from Michigan State University. She is an assistant professor of management at the University of Wisconsin-Whitewater. Her research interests include applicant and employee image management, workplace accommodations for employees with disabilities, and the applications of social media at work and in education. E-mail: delaneyk@uww.edu

Jeff Vanevenhoven earned his Ph.D. in Organizations and Strategic Management from the University of Wisconsin-Milwaukee. He is an Associate Professor of Management and the Entrepreneurship major coordinator of at the University of Wisconsin-Whitewater. His research includes organizational turnaround, entrepreneur bricolage, online learning, assessment, entrepreneurship education, microfinance, strategic management, and environmental uncertainty. His work has appeared or is forthcoming in publications such as Strategic Management Journal, Journal of Small Business Management, International Journal of Management Technology, New England Journal of Entrepreneurship, and Journal of Women's Entrepreneurship and Education. E-mail: delaneyk@uww.edu (Corresponding author)

Dick Wagner earned his Ph.D. in Human Resource Management from Indiana University. He is a Professor of Human Resource Management at the University of Wisconsin-Whitewater. His current research focuses on training and development, distance learning and a variety of staffing related issues. He is the co-author of two books and his work has appeared in Training and Development Journal, the Journal of Online Training, Healthcare Manager, and a variety of related journals. E-mail: wagnerr@uww.edu

John Chenoweth is the Associate Dean of the College of Business and Economics and a co-director of the Wisconsin Center for IT Services at UW-Whitewater. Prior to becoming associate dean, he was an associate professor and chair of the Information Technology and Business Education department. E-mail: chenowej@uww.edu

\section{REFERENCES}

1. Boice, R. (2000). Advice for new faculty members: Nihil nimus. Needham Heights, MA: Allyn \& Bacon.

2. Bonk, C. J. (2001). Online teaching in an online world. Bloomington, IN: CourseShare.com. Retrieved May 10, 2012 from http://www.courseshare.com/reports.php

3. Care, W. D., \& Scanlan, J. M. (2001). Planning and managing the development of courses for distance delivery: Results from a qualitative study. Online Journal of Distance Learning Administration, 4(2).

4. DeGagne, J. C., \& McGill, B. A. (2010). Ethical and legal issues in online education. Journal of eLearning and Online Teaching, 1(7).

5. Deubel, P. (2003). Learning from reflections-issues in building quality online courses. Online Journal of Distance Learning Administration, 6(3).

6. Gasaway, L. N. (2002). Drafting a faculty copyright ownership policy. The Technology Source, March/April.

7. Koehler, M. J., Mishra, P., Hershey, K., \& Peruski, L. (2004). With a little help from your students: A new model for faculty development and online course design. Journal of Technology and Teacher Education, 12(1), 25-55.

8. Kranch, D. A. (2008). Who owns online course intellectual property? The Quarterly Review of Distance Education, 9(4), 349-356.

9. Loddington, S., Gadd, L., Oppenheim, C., Bates, M., \& Manuel, S. (2006). Copyright ownership of teaching materials. Bristol, UK: Joint Information Systems Committee. Retrieved May 10, 2012 from https://dspace.lboro.ac.uk/dspaceispui/bitstream/2134/2702/1/CopyrightOwnership\%5b1\%5d.pdf

10. Massy, W. F., \& Zemsky, R. (1995). Using information technology to enhance academic productivity. EDUCOM NLII white paper. 
11. Miller, M. D., \& Rader, M. E. (2010). Two heads are better than one: Collaborative development of an online course template. MERLOT Journal of Online Teaching and Learning, 6(1), 246-255.

12. Morgan, G. (2000). Faculty ownership and control of digital course materials. Teaching with Technology Today, 5(4).

13. Petersen, R. P. (2003). Ownership of online course material. Boulder, CO: EDUCAUSE Center for Applied Research. Retrieved May 10, 2012 from http://www.net.educause.edu/ir/library/pdf/ERB0301.pdf

14. Porto, S., \& Aje, J. (2004). A framework for operational decision-making in course development and delivery. Online Journal of Distance Learning Administration, 7(2).

15. Seaman, J. (2009). Online learning as a strategic asset: Volume II: The paradox of faculty voices: Views and experiences with online learning.

16. Twigg, C. A. (2003). New models for online learning. EDUCAUSE Review, September/October, 28-38.

17. Wagner, R. J., Vanevenhoven, J. P., \& Bronson, J. W. (2010). A top ten list for successful online courses. MERLOT Journal of Online Teaching and Learning, 6(2), 1-4.

18. Xu, H., \& Morris, L. V. (2007). Collaborative course development for online courses. Innovation in Higher Education, 32, 35-47. 